\title{
Po Archaeology and the Late Modern WAC State: Introduction to the Special Issue
}

Richard M. Hutchings, Institute for Critical Heritage and Tourism, 330 Spruce Avenue, Gabriola Island, BC V0R 1X1, Canada

E-mail: rmhutchings@icht.ca

Joshua Dent, Sustainable Archaeology, Western University, 1600 Attawandaron Rd, London, ON N6G 3M6, Canada; Timmins Martelle Heritage Consultants Inc., London, ON, Canada

E-mail: jdent3@uwo.ca

\section{ABSTRACT}

While archaeologists have always shown great interest in the rise and fall of premodern states, they perennially show little interest in their own. This is particularly troubling because the state is the nexus of power in archaeology. In practice, virtually all archaeology is state archaeology, imbued with and emboldened by state power. It is in this light that contributors to this Special Issue of Archaeologies grapple with the archaeology-state nexus, addressing such timely issues as colonialism, capitalism, and cultural resource or heritage management (CRM/CHM). We outline here the archaeology-state nexus concept and introduce the Special Issue.

Résumé: Tandis que les archéologues ont toujours fait preuve d'un intérêt marqué pour l'ascension et la chute des États prémodernes, ils n'en démontrent que rarement envers le leur. Cet état des choses est particulièrement troublant, car l'État est le lieu de convergence des pouvoirs en archéologie. Dans la pratique, presque toute l'archéologie est une archéologie d'État, imprégnée et enhardie par le pouvoir étatique. C'est donc dans cet état d'esprit que les contributeurs de ce numéro spécial d'Archaeologies débattent de la connexion entre l'État et l'archéologie en traitant d'enjeux opportuns, notamment le colonialisme, le capitalisme et la gestion des ressources ou du patrimoine culturels. Nous définissons ici le concept de la connexion entre l'État et l'archéologie et présentons le numéro spécial.

Resumen: Aunque los arqueólogos siempre han mostrado un gran interés en el surgimiento y la caída de los estados premodernos, muestran 
incesantemente poco interés en sus propios estados. Esto es particularmente molesto porque el estado es el nexo de poder en la arqueología. En la práctica, virtualmente cualquier arqueología es arqueología del estado, imbuida con e incentivada por el poder estatal. Los que han contribuido a este Número Especial de Archaeologies tratan, desde este punto de vista, del nexo arqueología-estado, abordando temas tan oportunos como el colonialismo, el capitalismo y la gestión del patrimonio o de los recursos culturales (CRM/CHM, por sus siglas en inglés). Esbozamos aquí el concepto de nexo arqueología-estado y presentamos el Número Especial.

\section{KEY WORDS}

Statecraft, Governance, Diplomacy, Bureaucracy, Cultural resource management, Indigenous heritage, Heritage crime

\section{Introduction}

Contributors to this Archaeologies Special Issue consider the role of the state not just in archaeological thought and practice but heritage stewardship more broadly. The Special Issue developed from two conference sessions organized by the authors: "Archaeology and the State," convened at the 2015 meeting of the Society for American Archaeology, San Francisco, California, and "Heritage and the Late Modern State," convened at the 2016 meeting of the Association for Critical Heritage Studies, Montréal, Quebec.

As exemplified in the eight papers included here, the implications of the state for understanding how archaeology is imagined (Beaudoin 2016; Bernbeck and McGuire 2000; Custer 2005) and applied are significant and wide ranging (Bendix et al. 2012; Byrne 2008[1991]; Coombe 2012; Coombe and Baird 2016; Coombe and Weiss 2015; Díaz-Andreu 2014; Fowler 1987; Gnecco and Dias 2015; Harrison 2013; Hutchings 2017a, b; Hutchings and La Salle 2015a; King 2009; Kohl and Fawcett 1995; OyuelaCaycedo and Dever 2011; Miller 1980; Patterson 1999; Plets 2016a, b; Shnirelman 2014; Smith 2004). Central to this dynamic is social power (Smith 2004), defined as "the ability of individuals to influence other people and events" (Bodley 2003: 4).

Rather than an expansive global analysis, we seek in this Special Issue to attain a basic understanding of the conditions and contours of the archaeology-state nexus through local, regional, and continental case studies. Because the conferences took place in the USA and Canada, most of the 
examples are North American. Below, a discussion of late modernity and the archaeology-state nexus by Richard Hutchings provides his vision of these concepts, which authors in this Special Issue were asked to consider in their analyses. This is followed by an introduction to the contents of the Special Issue provided by Joshua Dent.

\section{The Archaeology-State Nexus: Richard M. Hutchings}

Archaeology in the service of the state is not something that just happened. Phillip Duke (2007)

I apply the term archaeology-state nexus to those aspects of the discipline and practice that are influenced or controlled by the state and its agents. Minimally, I take the state to be the "whole spectrum of government, including the behaviour of people at all levels of the civil service and related bureaucracies, agencies, departments, and offices" (Hale 1990: 579). From this standpoint, the state is synonymous with government, governance, and governmentality (Burchell et al. 1991; Dean 1999; Inda 2005).

In applying this definition to North America, for example, it is apparent that:

- virtually all archaeology performed is state-sanctioned, as cultural resource management (CRM) now constitutes upwards of 90 per cent of the practice (Birch 2006: 14; Ferris and Welch 2014: 74; Green and Doershuk 1998: 122; La Salle and Hutchings 2012: 10);

- virtually all academic archaeology is state-sanctioned, as most work is done in state institutions with state funding;

- virtually all academic archaeologists are state agents, as most are employed by thus responsible to the state;

- virtually all professional archaeologists are state agents insofar as most are paid to enforce state heritage regimes (i.e. compliance archaeology, or CRM); and

- the primary focus of archaeology is Indigenous heritage-thus living Indigenous people.

In this example of the archaeology-state nexus, the state's power to control living people by controlling heritage is the central focus, not scientific reconstructions of the past (Custer 2005; Smith 2004). According to Jay Custer (2005: 3), American archaeologists "have created a thought world which serves to support their own power and privilege, harms the interests 
of American Indian people, and aids the on-going cultural genocide [of] Native Americans." Laurajane Smith (2004: 195) concludes that archaeology/CRM is "ultimately about the management and governance of the meanings and values that the material heritage is seen to symbolize or otherwise represent." For Indigenous peoples, "what is often at stake is the right to control a sense of their own identity, which in turn can have vital implications in wider negotiations with governments and their bureaucracies over the political and cultural legitimacy of Indigenous interests." Through legislation, archaeology "plays a part in 'governing' populations and representations of their pasts" (Smith 2004: 197).

Of course, the archaeology-state nexus extends beyond North America and Indigenous heritage. But how different is it, ultimately, from the dynamic illustrated above? While one should certainly expect universal patterns (e.g. Agamben 2005; Armitage 1995; Bauman 2000; Berman 1988; Bodley 2014; Breton 1991; Bridge 2014; Brown 2006; Chambliss et al. 2010; Giddens 1990, 1991; González-Ruibal 2008; Hamilakis 2007; Held 1989; Hutchings 2017a; Kautsky 1980; Kimmel 2016; Maybury-Lewis 2002; Scott 1998; Simpson 2016), there are, no doubt, many exceptions, too. One universal I focus on here is modernity (Thomas 2004), in particular "late modernity," discussed below.

I have divided this short survey of the archaeology-state nexus into three parts. I begin by theorizing "the state" and "late modern state" and then consider the archaeology-state nexus. Central to this dynamic is the relationship between agency and structure.

\section{The State}

The term "state" in the compound "archaeology-state nexus" requires attention. Raymond Michalowski (2010: 23-24) notes how

In some studies...'the state' refers to the activities of actors in institutions of government. In others, it refers to a loosely defined linkage between economic and political institutions. Less common are analyses...that approach the state in a manner similar to what is typical of contemporary sociological and political science. In these fields the state is increasingly understood as a set of dynamic processes through which capital accumulation, political governance and ideological construction intersect to produce what might loosely be termed a socio-political order, but do so in such a fluid and interpenetrating manner that it becomes difficult to draw absolute boundary lines between, state, economy and culture.

By the latter half of the twentieth century, Western theorists began seeing the state "not as a thing - that is, an ensemble of geographically bound 
institutions and institutionally empowered individuals - but rather as a set of intersecting processes that both reproduce and alter the social order" (Michalowski 2010: 24).

As a result of these efforts (e.g. Block 1977; Foucault 1977, 1991; Jessop 1991; Poulantzas 1968), the following three characteristics of the modern state can be identified (Michalowski 2010: 24-25):

- Internally complex: High internal variability means those analysing state actions must be clear about what parts of the "structural ensemble" they are addressing (Michalowski 2010: 25).

- Ubiquitous: In addition to being internally complex, the effects of the state "appear in many arenas of social life well beyond the boundaries of state institutions" (Michalowski 2010: 25; see also Rose and Miller 2010). The dynamics of governmentality (Foucault 1977, 1991) "point to societies in which state effects penetrate and discipline human societies in ways that individuals both self-align their interests to those of the state and become part of the state by reproducing its ideology and its practices as part of their daily lives" (Michalowski 2010: 25; see also Kahan et al. 2011).

- Unintended consequences: States "unintentionally influence the formation of groups and the political capacities, ideas and demands of various sectors of society" (Skocpol 1985: 21; for example, see Duyvendak and Jasper 2015). In this regard, "we need to be attentive not just to the formal goals of the state as expressed by state agents, but all of the other social formations that exist either in supportive or oppositional reaction to the state" (Michalowski 2010: 25).

Theorizing the state, and thus the archaeology-state nexus, invariably resolves into discussions about structure and agency. An important example is the Miliband-Poulantzas debate from the 1970s (Miliband 1969; Poulantzas and Miliband 1972; for historical perspective, see Barrow 2002a, b, 2005, 2016).

The two key players in that debate were European sociologists Ralph Miliband, a proponent of the so-called instrumentalist theory of the state, and Nicos Poulantzas, an advocate of the opposing structuralist viewpoint. The debate started in 1969 with Miliband's claim that the state works in service of capitalism, the central thesis of his (then) new book The State in Capitalist Society. His rationale for the claim included the social construction of government and the strong social connections between government officials and the ruling elite. Poulantzas countered that capitalists work in service of the state, the rationale being that because the state is an objectively capitalist entity, it can serve no other purpose than the preservation of capitalism (i.e. the capitalist mode of production). In turn, Miliband 
noted how the structuralist view makes no allowance for human agency, making the whole position untenable. Poulantzas responded by noting that the state serves capitalist interests no matter who is in charge. The debate then faded into history, replaced by the globalization paradigm which envisioned the end of the state at the hands of global corporations (Barrow 2002a, b, 2016).

As in the Miliband-Poulantzas debate, understanding where power resides is key to understanding agency and structure at the archaeologystate nexus. What role do archaeologists play in supporting and carrying out state heritage regimes? Are they complicit in perpetrating state-sanctioned heritage crime (Hutchings and La Salle, this issue) or merely pawns in the game? Does it matter either way if their actions result in harm? As Michael Asch (2009: 394) asks about Canadian archaeology, "What could be more reasonable than a desire to ensure that you are the custodian of your own cultural heritage? And what could be more unreasonable than holding another people's cultural heritage, of ongoing significance to them, in your hands?"

Another useful point of departure for discussing agency and structure (and power and complicity) is Thomas Hobbes' Leviathan (1651), not just in terms of the book's thesis but also its famous frontispiece, notably its upper portion, shown here as Figs. 1 and 2. According to Hobbes, the state of nature-what he calls "the war of all against all" - can only be averted through a social contract and rule by an absolute sovereign overseeing a strong, unified government. With territory and citizenry under the sovereign leaders' total control-represented here by his towering position and scepter (ideological control) and sword (physical control) - the state is conceived of as a top-down, authoritarian affair. However, the sovereign only exists with the consent and support of individuals, as highlighted in Fig. 2; without them, there is no state.

Radcliffe-Brown (1940: xxiii) provides an excellent summary of the agency view of the state, particularly in light the Leviathan imagery:

In writings on political institutions there is a good deal of discussion about the nature and the origin of the state, which is usually represented as being an entity over and above the human individuals who make up a society, having as one of its attributes something called 'sovereignty,' and sometimes spoken of as having a will (law being often defined as the will of the state) or as issuing commands. The state, in this sense, does not exist in the phenomenal world; it is a fiction of the philosophers. What does exist is an organization, i.e. a collection of individual human beings connected by a complex system of relations. Within that organization different individuals have different roles, and some are in possession of special power or authority, as chiefs or elders capable of giving commands which will be obeyed, as legislators or judges, and so on. There is no such thing as the power of the 


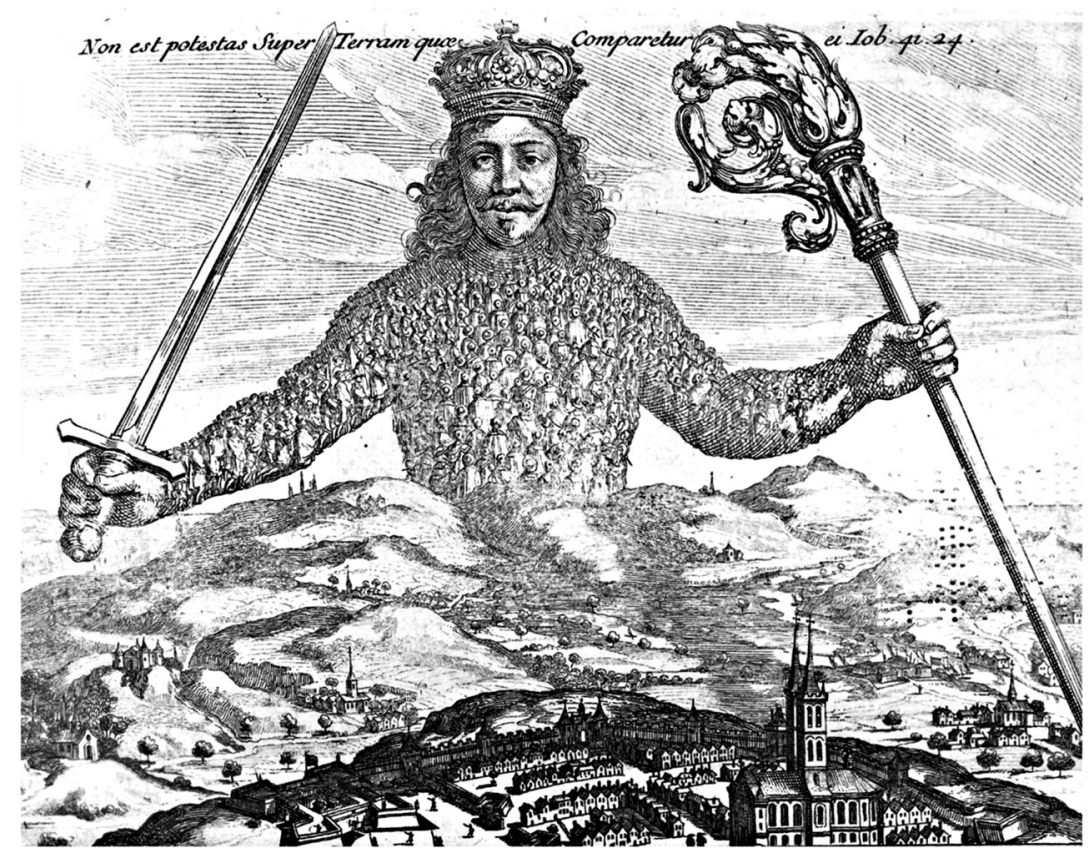

Figure 1. The frontispiece of Thomas Hobbes' Leviathan (1651) includes this detailed and symbol-laden representation of the state-society relationship. The quote above the leviathan's crown, taken from the Book of Job, reads "Non est potestas Super Terram quae Comparetur ei. lob. 41.24"- "There is no power on earth to be compared to him. Job 41.24." Abraham Bosse, 1651

state; there are only, in reality, powers of individuals — kings, prime ministers, magistrates, policemen, party bosses, and voters...

.... and archaeologists.

Debate over the primacy of agency or structure in shaping late modern state heritage regimes is limited in archaeological discourse (Dornan 2002; Plets 2016a), implying this powerfully conflicting yet dialectically entwined social force is largely taken for granted. Where agency is the ability of individuals to make their own choices (free will), structure is the social configuration that restricts or constrains choice. In light of the archaeology-state nexus, one might ask: How much agency does the average late modern citizen have over heritage? What is the role of the archaeologist in limiting that individual's choice? To what degree do archaeologists work in service of the state? Alternatively, how much agency does the typical archaeologist have when it comes to changing or "transforming" (La Salle and Hutchings 2015,2016$)$ the state heritage regime they serve? 


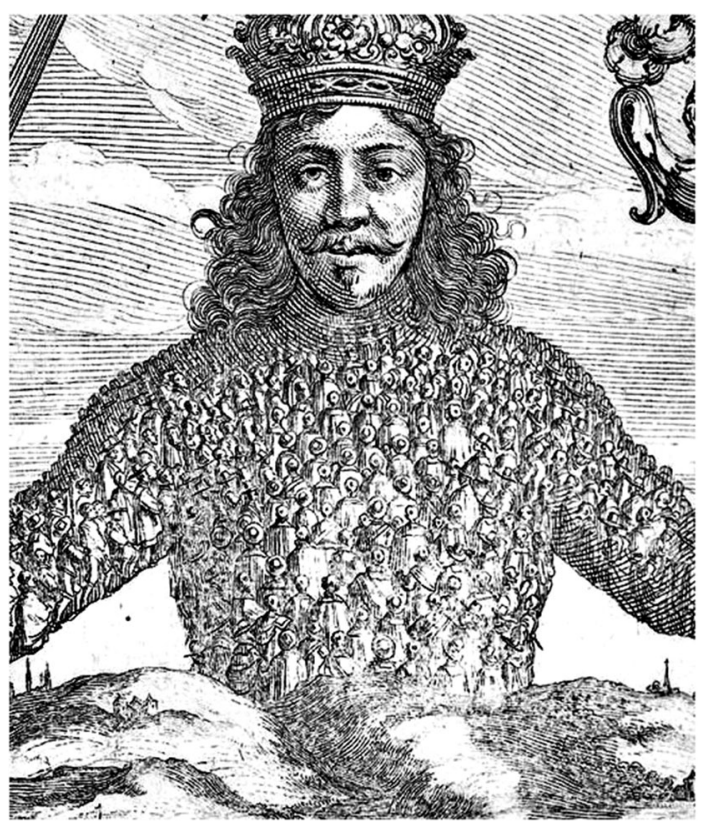

Figure 2. The leviathan's torso-representing the "body politic"-is comprised of the citizenry (individuals) over whom the sovereign rules (governs) not by force, according to Hobbes, but by consent. The notion of consent is indicated in the frontispiece by the leviathan's exposed position and in the way all the individuals are looking upward at the head (of state), implying reverence and wilful service. Abraham Bosse, 1651

Set in dialectic opposition to agency is structure, formulated as "structuration" by sociologist Anthony Giddens (1984; see also Bryant and Jary 1991; Dornan 2002). Building on Karl Marx's observation that individuals "make history, but not in circumstances of their own choosing," structuration theory holds that socio-legal institutions like archaeology

are created by knowledgeable actors (or agents) within a specific social context (or structure). The structure-agency relationship is mediated by a series of institutional arrangements that both enable and constrain action. Hence three levels of analysis can be identified: structures, institutions, and agents. Structures include the long-term, deep-seated social practices that govern daily life, such as law and the family. Institutions represent the phenomenal forms of structures, including for example, the state apparatus. And agents are those influential human actors who determine the precise, observable outcomes of any social interaction. (Dear and Wolch 1989: 6)

Commonly cited structural constraints in archaeology include modernity, capitalism, the academy, and cultural resource management, all of which 
are state-sanctioned projects, directly or indirectly. Another commonly identified constraint is bureaucracy, which once fully established "is among those social structures which are the hardest to destroy" (Weber 1987: 987). Problematically,

\begin{abstract}
Bureaucracy is everywhere. The modernist desire for rational government (Scott 1998) and repetitive day-to-day engagement with procedures and objects signifying rules and laws has ensured that across the world archaeologists have become enmeshed in an unclear web of agencies, official inspectors and procedures. Rules and documentary proof are such an intrinsic part of our everyday practices that they not only structure our epistemologies, but also have caused us to become blind to the subtle but powerful forms of political domination that underlie them. (Plets 2016a: 196)
\end{abstract}

Noting the many prominent social scientists that have mapped "the multitude of bureaucratic technologies - ranging from permits and statistics to grant systems-skilfully administered by the state to create governable subjects through the managed internalization of ideologies and hierarchies," Gertjan Plets (2016a: 196a) concludes

archaeologists' re-enactment of bureaucratic procedures, and dependency on official legal documents granting them stewardship over the past, effectuate the state's verticality (the state is above society) and encompassment (the state holds its subjects within), ultimately making archaeologists one of the many agents reproducing the state.

\title{
The Late Modern State
}

It is now increasingly realized that archaeology as we know and practice it...is a device of modernity, that is, the constellation of social, economic, cultural and ideological processes that shaped the west in the centuries from the end of the Middle Ages to the present. [M]odernity...established the ideas and the realities of nation-states [and] created the new regime of capitalism. Yannis Hamiliakis

There are political consequences to modernization (Bodley 2003, 2014; Giddens 1990; Kautsky 1980; Maybury-Lewis 2002), and archaeology is one of them (Hamilakis 2007; Thomas 2004; Trigger 2006). While archaeology is assuredly a product of modernity, the practice's post-1950 configuration suggests something entirely new-or at least significantly different-than what came before (e.g. Hutchings and La Salle 2015a, b; King 2009; Smith 2004). I thus employ the term "late modern" to highlight these differences. 
Conceptually, late modernity (1950-present) is related to high modernity, liquid modernity, late capitalism, and supermodernity.

James C. Scott's 1998 book Seeing Like a State: How Certain Schemes to Improve the Human Condition Have Failed is a good point of departure here. Scott describes high modernism and "the processes whereby hierarchical organizations, of which the most striking example is the state, create legible social and natural landscapes in the interest of revenue, control, and management" (Scott 2010: n.p.). A post-1900 Western ideology, high modernity is distinguished by the exaggeration of the four characteristics of modernity: (1) a strong confidence in the potential for scientific and technological progress, including a reliance thus dependence on experts such as scientists and bureaucrats; (2) the expansion of production; (3) the mastery of nature, including human nature; and (4) the rational design of social order towards efficiency and development (Scott 1998: 4-5). According to Scott (1998: 4), "the most tragic episodes of state-initiated social engineering originate in a pernicious combination of [the] four elements."

Late modernity also has much in common with liquid modernity; Zygmunt Bauman's (2000) attempt to describe the sociocultural meaning of global capitalist economies (globalization) and increasing privatization (neoliberalization). The "liquid" in liquid modernity is in part a reference to the increasing speed at which things change (or flow) today when compared to fifty or one-hundred years ago, when social institutions were more "solid" (Berman 1988; Giddens 1990). If "solid" is the legal-bureaucratic authority (Lee 2005: 63), then "[m] dernity is solid in the sense that the combined power of these interlocking institutions overwhelms any individual effort to keep tradition in place, and makes 'Western expansion seemingly irresistible' (Giddens 1990: 63)." According to Raymond Lee (2005:66), liquid modernity is Bauman's idea of "how the world today denies the so-called solidity that it once struggled assiduously to create and maintain." For Bauman (2000: viii), "Forms of modern life may differ in quite a few respects-but what unites them all is precisely their fragility, temporariness, vulnerability and inclination to constant change. To 'be modern' means to modernize-compulsively, obsessively; not so much just 'to be."'

In a similar vein, archaeologist Alfredo González-Ruibal (2008: 247; after Augé 1995) explores supermodernity (post-World War I to present), a concept that encompasses "the revolution of speed, new modes of communication and transportation, and new spatial relations" (i.e. contemporary Western society [Colville 2016; Dicken and Lloyd 1981; Giddens 1990]). Equating supermodernity with late capitalism (1947-present) and the "production of destruction," González-Ruibal (2008: 254,249) explains how the supermodern culture is "characterized by destruction as much as by pro- 
duction or consumption" and has, via globalization, spread to all corners of the planet.

I use the term late modern (Giddens 1991) as a catch-all for the aforementioned concepts. In the broadest sense, it refers to the "excessive," "super"-, or "hyper"-form of modernity under which most people on the planet live and operate today. More specifically, it is the post-1950 world characterized by rapid change and increasing global socio-ecological breakdown (Colville 2016; Fassbinder 2016; Hutchings 2017a; McNeill and Engelke 2014; Moore 2016). I thus see late modernity as a useful framing device for analysing and discussing contemporary heritage regimes, especially given that most were developed during the period (e.g. resource management).

\section{The Archaeology-State Nexus}

Who controls the past controls the future: who controls the present controls the past.

George Orwell (1949)

Benedict Anderson (1991) outlines the history of modern state formation, discussing the larger social functions of museums and universities as ideological state apparatus. Archaeology, another mechanism by which the past is constructed and controlled, falls into this category (Hutchings and La Salle 2014, 2015a). In his analysis of the archaeology-state nexus in North America, Don Fowler (1987: 241) describes how, "[s]ince its inception as a field of study and later as a discipline, archaeology has been immersed in, and conditioned by, the economic, political, and governmental institutions of nation states." He provides this useful spectrum of state control:

In various nation states at various times, some archaeologists have analyzed and interpreted the past to fit the ideological requirements of those states. That is one end of the spectrum. The other is the implicit and therefore unquestioned acceptance of ideological tenets and values from within the archaeologist's culture and how they influence the archaeologist's uses of the past.

Similarly, and more recently, Regina Bendix, Aditya Eggert, and Arnika Peselmann illustrate in their edited volume Heritage Regimes and the State how (1) "a state's political history leaves a mark on all heritage regimes" and (2) "[h] eritage-making is never pursued simply for the sake of preserving and safeguarding" (Bendix et al. 2012: 17,18). They discuss the heritage-state nexus in terms of the regime, a "set of rules and norms regulating the relations between a state-government and society" (2012: 12; 
see esp. De Cesari 2012). The regime concept is important because it necessarily expands the definition of the state beyond government, and even beyond economy, to include society.

Historically, most archaeology-state research has focused on nationstates, emphasizing nationalism (Díaz-Andreu 2014; Kohl 1998; Kohl and Fawcett 1995; Shnirelman 2014). This attention makes sense in light of Bruce Trigger's (1984: 358) observation that "most archaeological traditions are probably nationalistic in orientation." Yet, the archaeology-state nexus has many facets, and all demand attention if the goal is a comprehensive, holistic understanding of the practice.

Laurjane Smith's 2004 book Archaeological Theory and the Politics of Cultural Heritage constitutes the contemporary theoretical benchmark for archaeology-state nexus discourse. Writing about archaeology in such colonial contexts as Australia, Canada, and the USA, Smith theorizes archaeology as a colonial project, a "technology of government" designed to control the heritage thus identity of living Indigenous peoples. Because "archaeological knowledge enters into state strategies concerned with the governance of Indigenous cultural identity," the institution cannot claim neutrality, intellectually or politically (Smith 2004: 12).

Smith elucidates the "dominant Western discourse about heritage," what she calls authorized heritage discourse (AHD), a worldview that operates to "naturalize a range of assumptions about the nature and meaning of heritage" (2004: 4-5). AHD is professional discourse that "privileges expert values and knowledge about the past and its material manifestations, and dominates and regulates professional heritage practices." As a technology of government, archaeology becomes "mobilized in the regulation of populations" (2004: 2-3).

One of the most pronounced characteristics of the late modern archaeology-state nexus is neoliberalism, although the subject has been largely overlooked by archaeologists until quite recently (Coombe 2012; Coombe and Baird 2016; Coombe and Weiss 2015; Hutchings and La Salle 2015a; Plets 2016a). Rosemary Coombe and Lindsay Weiss (2015: 44) note that "Many heritage scholars characterize neoliberalism as an ideology privileging economic rationality that has contributed to a profit driven conception of heritage; others describe it as 'an ideological approach to the state's role in economy and society' (Gattinger and Saint-Pierre 2010: 280).”

Coombe and Weiss' work shows how neoliberalized heritage regimes have "a strong tendency to obscure environmental impacts" and to "reframe contentious debates in a celebratory language of partnership that ignores power relations" (2015: 340); 
Corporate discourse contains, manages, and packages heritage in nostalgic, ahistorical, and apolitical ways, and presents a view of good governance that ignores issues of coercion, levels of political recognition, and struggles to control lands and identities. Ongoing contested claims are presented as resolved and indigenous communities are unilaterally represented as partners in development projects in which they have had little if any choice.

This conceptualization fits well with ideas of late modern heritage as future-making, in particular economic future-making (Harrison 2013; Zetterstrom-Sharp 2015). Scott (1998: 95) describes the focus of late modernity as economic and "almost exclusively on the future...the past is an impediment, a history that must be transcended." Coombe (2012: 378) echoes these sentiments, noting late modern heritage regimes are "increasingly neoliberal," representing the "new dominance of market ideologies." Indeed, late modern states produce heritage that "has very little to do with the past" (Harrison 2013: 35); rather, it is shown to be focused on the assembly of a common economic future while erasing undesirable pasts. In this context, contemporary heritage constitutes little more than "a resource for new forms of capital accumulation" (Coombe and Weiss 2015: 43) and "local communities" are reduced to mere "stakeholders" (2015: 337).

\section{Confronting Agency}

If we understand who are the principal agents that have shaped archaeology and its agendas, it becomes clearer why and how archaeology takes particular structures in different nation-states. Augusto Oyuela-Caycedo and Alejandro Dever

This Special Issue illustrates the diverse range of views that exist in archaeology on what constitutes the archaeology-state nexus and the roles archaeologists play within it. Some archaeologists confront head-on the myriad ways the late modern state threatens humanity by threatening its life-sustaining heritage. But these critical engagements are not what linger in my mind; rather, what stands out is the persistent and formulaic response of mainstream archaeologists to late modernity, which is to whitewash their practice and blame someone else.

Rather than seeing themselves as integral components of the heritage-industrial complex (King 2009; Smith 2004), many archaeologists simply reframe archaeology as good and archaeologists as saviours. There is no affirmation of archaeology as a destructive technology of government. There is no recognition of how archaeologists are the state (Fig. 2). 
Erasing archaeology's inconvenient truths in pursuit of the missionary narrative is not unusual. Rather, in light of Chip Colwell's 2016 celebratory rebranding of archaeology in the prestigious Annual Review of Anthropology, this approach should now be understood as institutional status quo. Yet, such naïve and dangerous assertions cannot be left unattended.

Noam Chomsky's 1967 essay on the Responsibility of Intellectuals is especially relevant today (Parini 2017), as demonstrated here. Chomsky (1967: n.p.) posited that

Intellectuals are in a position to expose the lies of governments, to analyze actions according to their causes and motives and often hidden intentions. In the Western world at least, they have the power that comes from political liberty, from access to information and freedom of expression. For a privileged minority, Western democracy provides the leisure, the facilities, and the training to seek the truth lying hidden behind the veil of distortion and misrepresentation, ideology, and class interest through which the events of current history are presented to us.

Unfortunately, archaeologists' perennial inability to confront their role as state agents means they cannot be trusted (Smith 2004: 12). The best advice I have, therefore, is to follow Karl Marx (and Chomsky) in calling for "ruthless criticism of all that exists, ruthless both in the sense of not being afraid of the results it arrives at and in the sense of being just as little afraid of conflict with the powers that be" (Marx 1997[1843]: 203).

\section{The Special Issue: Joshua Dent}

Seven of the eight papers in this Special Issue concern North America, and five are about Canada. Nevertheless, because of modernity and globalization, many of the lessons provided are relevant elsewhere. This is the essence of the late modern heritage environment. In their totality, the papers provide the background, contemporary nuance, and a sense of scope of current interactions between heritage research/management and the late modern state. Heritage generally and archaeology specifically are wielded by the state's various component parts subject to the characteristics of the modern state (see previous section) but heritage is also wielded, or capable of being deployed, by those resistant to, or seeking alteration of, broader state controls and narratives. These papers recognize that heritage is simultaneously an "authorized discourse" (Smith 2004) projecting from the state and an invasive "activist conduit" into state processes and logics. In briefly describing each paper, as follows, almost contradictory threads of perdition and promise pervade the narratives emphasizing and, given when 
these papers were drafted, almost anticipating the current unsettled governance environment.

Jeremy Wells's commentary on American historical preservation begins by situating the development of state heritage intervention in the early to mid-twentieth century's positivist quest for "truth." The reverberations of this period are still felt today, and this historical context certainly has relevance to the other papers of this issue. Wells indicates that not only is contemporary state heritage regulation consistent with regulation enacted during this early period, but the nature of this positivistic approach restricted valuation of heritage resources to cadres of heritage discipline "experts." Framing his commentary in terms of etic and emic, outsider/physical and insider/emotional, Wells dissects the motivations behind expert state and commercial heritage preservation. He laments the codification of simplistic and efficient heritage preservation and valuation practices but holds out hope that a more dynamic and adaptable future will prevail. His commentary resonates with later papers (Dent; Hogg, Welch and Ferris; McCormack) in anticipating and advocating for meaningful changes in state heritage preservation approaches.

Paulette Steeves describes the consequences of both failing to acknowledge other means of history-making outside of archaeology and failing to overturn, or at least challenge, outdated archaeological orthodoxy, namely the Clovis First hypothesis of the peopling of the Western Hemisphere. She outlines the contemporary links between Indigenous mental health and cultural revitalization, arguing that archaeology can no longer ignore the consequences of maintaining destructive colonial paradigms that erase past Indigenous diversity and continuums of presence. Steeves's paper reinforces a primary pillar of this Special Issue: that heritage research and management is not a passive activity and that failure to acknowledge as much replicates the very worst elements of colonialism. Steeves sees potential in archaeology to provide some remedy, but until the discipline overcomes its colonially premised dogma archaeology can and continues to do great damage.

Richard Hutchings and Marina La Salle elaborate on the structural harm archaeology is capable of inflicting due in large part to the discipline's relationship with and role within the late modern state (see also Steeves this issue). Drawing from separate state and heritage crime theory discourses, Hutchings and La Salle conceptualize North American archaeology as a state heritage crime. Their conceptualization forces a disrupted perspective of archaeology that will be uncomfortable for many archaeologists. This perspective is unsettling precisely because of how the state defines and characterizes harm, violence, and crime. By broadening the definition to include state actions, Hutchings and La Salle successfully co-opt that char- 
acterization, which the state nurtures in society. They then direct that aversion into a critical appraisal of the role of archaeology.

Gary Warrick provides a comprehensive example of dynamic state-commercial-Indigenous heritage interactions in his account of contemporary Ontario's archaeological practices. His paper provides an accurate depiction of the many elements and processes interacting within a single jurisdiction's heritage management system. The varying motivations and contexts within the Canadian province revolve around multiple provincial regulations and sequences of heritage management events. Warrick emphasizes that Indigenous communities are not simply passive participants in these processes but are cognizant of state motivations and negotiate their roles in the heritage management process accordingly. This paper exemplifies that while the concepts presented in this Special Issue might have universal relevance, the application and realization of these concepts must account for the variability and nuance expressed locally.

Patricia McCormack's paper reinforces the importance of local circumstances detailing how the absence of regard for Indigenous trails and landscapes in Alberta's provincial heritage regulations affects the cohesiveness of Indigenous culture, particularly in the oil sands-rich areas of Northern Alberta. McCormack establishes that just as state heritage intervention has consequences so too does state nonintervention. In failing to identify trails and other Indigenous-altered landscapes alongside other formally protected heritage resources, the province replicates the etic/emic divide (Wells this issue). It also rejects contemporary research in favour of dated positivistic dogma (see Steeves this issue). McCormack problematizes the nature of state heritage intervention as perhaps needing, at least in certain circumstances, to be more intensive rather than less so.

My paper pulls back from looking at one specific instance of archaeology-state interaction and addresses a growing series of Canadian Indigenous-settler state agreements and contemporary treaties in which heritage management is addressed. My cross-jurisdictional review demonstrates a formalized and negotiated recognition of local heritage idiosyncrasies in both the differences in content and devolution of authorities in these agreements. I postulate that this contemporary process of passing authority has not yet resulted in a seismic shift in heritage management practices. However, the power and potential for change is embedded within many of these agreements. My paper maintains that state heritage structures can persist beyond direct state oversight and that shifting authority alone may not be enough to substantively change archaeological practice.

Amy Clarke's paper takes us beyond both archaeology and national boundaries chronicling the establishment and subsequent dormancy of the "List of Overseas Places of Historic Significance to Australia." Clarke's investigation into this extra-territorial heritage policy outlines the colonial, 
Euro-centric and White male-dominated heritage narratives exemplified in the places selected to appear on the list (also those that were investigated but not selected). Clarke points to an apparently conscious balancing of military and intellectual accomplishments and contextualizes that balancing within state attempts to author a more intellectual national heritage narrative. This paper clearly demonstrates the ability of the late modern state to strategically interpret and preserve heritage linked to nationalistic narratives even when that heritage exists beyond that state's borders. The paper also represents the contemporary low-profile of Australia's Overseas Places List suggesting that such policies may not be worth the time and diplomatic capital expended in their compilation.

Erin Hogg, John Welch, and Neal Ferris outline the concept of Full Spectrum Archaeology (FSA) in relation and in opposition to neoliberal state heritage management. They establish FSA as a comprehensive acknowledgement and deployment of multiple approaches and values encompassing archaeological practice. In advocating for FSA, the authors knit together international heritage standards, prevailing "inheritor" community authorities and values, and professional archaeological motivations and ethics. These elements stand in opposition to late modern state heritage practices grounded in a neoliberal orthodoxy. An orthodoxy which is increasingly divorced from the promise and potential public "good" represented within FSA approaches to archaeological management. These approaches consciously recognize "the power and privilege" inherent to archaeological practice, promoting heritage outcomes of service beyond archaeology.

All of the papers in this Special Issue position heritage as a mechanism for those serving and those resisting conceptualizations of the late modern state. The powers and authorities wielded by individuals and institutions capable of defining heritage and delineating the processes through which heritage is managed and commemorated are of increasingly recognized significance. Late modern state oversight of heritage as expressed in these papers artificially streamlines, simplifies, and constricts the possibilities of heritage research and resource management. In the worst cases presented here, this orthodoxy maintains and seeks to legitimate oppressive systems capable of inflicting physical harm and institutional violence on Indigenous and other inheritor/descendant communities. Yet even within this acknowledgement of state-based heritage management limitations and afflictions, many of these papers offer up possibility. Possibilities which revolve around increasingly "glocal" phenomena whereby international and other trans-jurisdictional heritage standards are realized in locally defined ways. The hope for the future of or beyond late modern state heritage management lies in adaptable, dynamic, restorative local expressions of authority, however, derived, within a trans-jurisdictional awareness and responsibility. 


\section{References}

Agamben, G.

2005. State of Exception (trans. K. Attell). University of Chicago Press, Chicago, IL.

Anderson, B.

1991. Imagined Communities: Reflections on the Origin and Spread of Nationalism. Verso, London.

Armitage, A.

1995. Comparing the Policy of Aboriginal Assimilation: Australia, Canada, and New Zealand. UBC Press, Vancouver, BC.

Asch, M.

2009. Concluding Thoughts and Fundamental Questions. In Protection of First Nations Cultural Heritage: laws, Policy, and Reform, edited by C. Bell and R.K. Paterson, pp. 394-411. UBC Press, Vancouver, BC.

Augé, M.

1995. Non-Places: Introduction to the Anthropology of Supermodernity. Verso, London.

Barrow, C.W.

2002. The Miliband-Poulantzas Debate: An Intellectual History. In Paradigm Lost: Revisiting State Theory, edited by S. Aronowitz and P. Bratsis, pp. 352. University of Minnesota Press, Minneapolis, MI.

2005. The Return of the State: Globalization, State Theory, and the New Imperialism. New Political Science 27(2):123-145.

2016. Toward a Critical Theory of States: The Poulantzas-Miliband Debate After Globalization. State University of New York Press, Albany, NY.

Bauman, Z.

2000. Liquid Modernity. Polity Press, Cambridge.

Beaudoin, M.

2016. Archaeologists Colonizing Canada: The Effects of Unquestioned Categories. Archaeologies 12(1):7-37.

Bendix, R.F., A. Eggert, and A. Peselmann

2012. Heritage Regimes and the State. Göttingen Studies in Cultural Property, Volume 6. Universitätsverlag Göttingen, Göttingen.

Berman, M.

1988. All That is Solid Melts into Air: The Experience of Modernity. Penguin, New York. 
Bernbeck, R., and R.H. McGuire

2000. A Conceptual History of Ideology and its Place in Archaeology. In Ideologies in Archaeology, edited by R. Bernbeck and R.H. McGuire, pp. 15-59. University of Arizona Press, Tucson, AZ.

Birch, J.

2006. Public Archaeology and the Cultural Resource Management Industry in Southern Ontario. Unpublished Master's Thesis, Department of Sociology and Anthropology, Carleton University, Ottawa, ON.

Block, F.

1977. The Ruling Class Does Not Rule: Notes on the Marxist Theory of the State. Socialist Revolution 7(33):6-28.

Bodley, J.H.

2003. The Power of Scale: A Global History Approach. M. E, Sharpe, Armonk, NY.

2014. Victims of Progress (6th ed.). Rowman, Malden, MA.

Breton, R.

1991. The Governance of Ethnic Communities: Political Structures and Processes in Canada. Greenwood Press, New York, NY.

Bridge, G.

2014. Resource Geographies II: The Resource-State Nexus. Progress in Human Geography 38(1):118-130.

Brown, W.

2006. Finding the Man in the State. In The Anthropology of the State, edited by A. Sharma and A. Gupta, pp. 187-210. Blackwell, Oxford.

Bryant, C.G.A., and D. Jary (editors)

1991. Gidden's Theory of Structuration: A Critical Appreciation. Routledge, London.

Burchell, G., C. Gordon, and P. Miller (editors)

1991. The Foucault Effect: Studies in Governmentality. University of Chicago Press, Chicago.

Byrne, D.

2008 [1991]. Western Hegemony in Archaeological Heritage Management. In The Heritage Reader, edited by G. Fairclough, R. Harrison, J.H. Jameson, and J. Schofield, pp. 229-234. Routledge, London. Originally published in History and Archaeology 5:269-276.

Chambliss, W.J., R. Michalowski, and R.C. Kramer (editors)

2010. State Crime in the Global Age. Willan Publishing, Devon. 
Chomsky, N.

1967. The Responsibility of Intellectuals. The New York Review of Books 8(3). Electronic document, https://chomsky.info/19670223/. Accessed 11 February 2017.

Colville, R.

2016. The Great Acceleration: How the World is Getting Faster. Faster, Bloomsbury.

Colwell, C.

2016. Collaborative Archaeologies and Descendent Communities. Annual Review of Anthropology 45:1-15.

Coombe, R.J.

2012. Managing Cultural Heritage as Neoliberal Governmentality. In Heritage Regimes and the State, edited by R. F. Bendix, A. Eggert, and A. Peselmann, pp. 375-387. Göttingen Studies in Cultural Property, Volume 6. Universitätsverlag Göttingen, Göttingen.

Coombe, R.J., and M.F. Baird

2016. The Limits of Heritage: Corporate Interests and Cultural Rights on Resource Frontiers. In A companion to Heritage Studies, edited by W. Logan, M.N. Craith, and U. Kockel, pp. 337-354. Wiley-Blackwell, New York.

Coombe, R.J., and L.M. Weiss

2015. Neoliberalism, Heritage Regimes, and Cultural Rights. In Global Heritage: A Reader, edited by L. Meskell, pp. 43-69. New York, NY, Wiley-Blackwell.

Custer, J.F.

2005. Ethics and the Hyperreality of the Archaeological Thought World. North American Archaeologist 26:3-27.

De Cesari, C.

2012. Thinking through Heritage Regimes. In Heritage Regimes and the State, edited by R. F. Bendix, A. Eggert, and A. Peselmann, pp. 399-413. Göttingen Studies in Cultural Property, Volume 6. Universitätsverlag Göttingen, Göttingen.

Dean, M.

1999. Governmentality: Power and Rule in Modern Society. Sage, London.

Dear, M., and J. Wolch

1989. How Territory Shapes Social Life. In The Power of Geography, edited by J. Wolch, and M. Dear, pp. 3-18. Unwin Hyman, Boston, MA.

Díaz-Andreu, M.

2014. Nationalism and Archaeology. In Encyclopedia of Global Archaeology, edited by C. Smith, pp. 5144-5149. Springer, New York, NY. 
Dicken, P., and P.E. Lloyd

1981. Modern Western Society. Harper and Row, London.

Dornan, J.L.

2002. Agency and Archaeology: Past, Present, and Future Directions. Journal of Archaeological Method and Theory 9(4):303-329.

Duke, P.

2007. Archaeology in Capitalism, Archaeology as Capitalism. In Archaeology and Capitalism: From Ethics to Politics, edited by Y. Hamilakis, and P. Duke, pp. 115-117. Routledge, London.

Duyvendak, J.W., and J.M. Jasper (editors)

2015. Breaking Down the State: Protestors Engaged. Amsterdam University Press, Amsterdam.

Fassbinder, S.D.

2016. The Literature of the Anthropocene: Four Reviews. Capitalism Nature Socialism . doi:10.1080/10455752.2016.1245918.

Foucault, M.

1977. Discipline and Punish: The Birth of the Prison (trans. A. Sheridan). Vintage, New York, NY.

1991. Governmentality. In The Foucault Effect: Studies in Governmentality, edited by Burchell, G. et al, pp. 87-104. University of Chicago Press, Chicago, IL.

Fowler, D.D.

1987. Uses of the Past: Archaeology in the Service of the State. American Antiquity 52:229-248.

Ferris, N., and J.R. Welch

2014. Beyond Archaeological Agendas: In the Service of a Sustainable Archaeology. In Transforming Archaeology: Activist Practices and Prospects, edited by S. Atalay, L.R. Clauss, R.H. McGuire, and J.R. Welch, pp. 215-237. Left Coast Press, Walnut Creek, CA.

Gattinger, M., and D. Saint-Pierre

2010. The "Neoliberal Turn" in Provincial Cultural Policy and Administration in Québec and Ontario: The Emergence of "Quasi-Neoliberal" Approaches. Canadian Journal of Communication 35(2):279-302.

Giddens, A.

1984. The Constitution of Society: Outline of the Theory of Structuration. University of California Press, Berkeley and Los Angeles, CA.

1990. The Consequences of Modernity. Polity Press, Cambridge.

1991. Modernity and Self-Identity: Self and Society in the Late Modern Age. Polity Press, Cambridge. 
Gnecco, C., and A.S. Dias (guest editors)

2015. Special Issue: On Contract Archaeology. International Journal of Historical Archaeology 19(4):687-842.

González-Ruibal, A.

2008. Time to Destroy: An Archaeology of Supermodernity. Current Anthropology 49(2):247-279.

Green, W., and J.F. Doershuk

1998. Cultural Resource Management and American Archaeology. Journal of Archaeological Research 6(2):121-167.

Hale, S.M.

1990. Controversies in Sociology. Copp Clark Pitman, Mississauga, ON.

Hamilakis, Y.

2007. From Ethics to Politics. In Archaeology and Capitalism: From Ethics to Politics, edited by Y. Hamilakis, and P. Duke, pp. 15-40. Routledge, London.

Harrison, R.

2013. Heritage: Critical Approaches. Routledge, London.

Held, D.

1989. Political Theory and the Modern State. Stanford University Press, Stanford, CA.

Hobbes, T.

1651 [2002]. Leviathan (edited by A. P. Martinich). Broadview, Peterborough, ON.

Hutchings, R.M.

2017a. Maritime Heritage in Crisis: Indigenous Landscapes and Global Ecological Breakdown, RoutledgeLondon.

2017b. Trump Exposes Hypocrisy of American Archaeology. Institute for Critical Heritage and Tourism January 23. Electronic document, https://critical heritagetourism.com/2017/01/23/trump-exposes-hypocrisy-of-americanarchaeology/. Accessed 11 February 2017.

Hutchings, R.M., and M. La Salle

2014. Teaching Anti-Colonial Archaeology. Archaeologies 10(1):27-69.

2015a. Archaeology as Disaster Capitalism. International Journal of Historical Archaeology 19:699-720.

2015b. Why Archaeologists Misrepresent Their Practice: A North American Perspective. Journal of Contemporary Archaeology 2(2):S11-S17.

Inda, J.X. (editor)

2005. Anthropologies of Modernity: Foucault, Governmentality, and Life Politics. Blackwell, Oxford. 
Jessop, B.

1991. State Theory: Putting the Capitalist State in Its Place. Pennsylvania State University Press, State College, PA.

Kahan, D.M., H. Jenkins-Smith, and D. Braman

2011. Cultural Cognition of Scientific Consensus. Journal of Risk Research 14(2):147-174.

Kautsky, J.H.

1980. The Political Consequences of Modernization. Robert E. Kreiger Publishing, New York, NY.

Kimmel, M.

2016. The Gendered Society (6th ed.). Oxford University Press, London.

King, T.F.

2009. Our Unprotected Heritage: Whitewashing the Destruction of Our Cultural and Natural Environment. Left Coast Press, Walnut Creek, CA.

Kohl, P.L.

1998. Nationalism and Archaeology: On the Constructions of Nations and the Reconstructions of the Remote Past. Annual Review of Anthropology 27:223-246.

Kohl, P.L., and C. Fawcett (editors)

1995. Nationalism, Politics and the Practice of Archaeology. Cambridge University Press, Cambridge.

La Salle, M., and R.M. Hutchings

2012. Commercial Archaeology in British Columbia. The Midden 44(2):8-16.

2015. Review of Transforming Archaeology: Activist Practices and Prospects. Canadian Journal of Archaeology 39:359-362.

2016. What Makes Us Squirm-A Critical Assessment of Community-Oriented Archaeology. Canadian Journal of Archaeology 40(1):164-180.

Lee, R.L.M.

2005. Bauman, Liquid Modernities and Dilemmas of Development. Thesis Eleven 83:61-77.

McNeill, J.R., and P. Engelke

2014. The Great Acceleration: An Environmental History of the Anthropocene Since 1945. Harvard University Press, Cambridge.

Marx, K.

1997[1843]. Letters from the Deutsch-Französische Jahrbücher. A Letter to Ruge in September 1843. In Writings of the Young Marx on Philosophy and Society, edited by L.D. Easton and K.H. Guddat, pp. 203-215. Hackett Publishing, Indianapolis, IN. 
Maybury-Lewis, D.

2002. Indigenous Peoples, Ethnic Groups, and the State. Allyn and Bacon, Boston, MA.

Michalowski, R.

2010. In Search of 'State and Crime' in State Crime Studies. In State Crime in the Global Age, edited by W.J. Chambliss, R. Michalowski, and R.C. Kramer, pp. 13-30. Willan Publishing, Devon.

Miliband, R.

1969. The State in Capitalist Society. Weidenfeld and Nicolson, London.

Miller, D.

1980. Archaeology and Development. Current Anthropology 21(6):709-726.

Moore, J. (editor)

2016. Anthropocene or Capitalocene? Nature, History, and the Crisis of Capitalism. PM Press, Oakland, CA.

Orwell, G.

1949. Nineteen Eighty-Four. Signet Classics, New York, NY.

Oyuela-Caycedo, A., and A. Dever

2011. The Agency of Academic Archaeology in Colombia. In Comparative Archaeologies: A Sociological View of the Science of the Past, edited by L.R. Lozny, pp. 613-639. Springer, New York, NY.

Parini, J.

2017. Noam Chomsky's 'Responsibility of Intellectuals' after 50 Years: It's an Even Heavier Responsibility Now. Salon February 11. Electronic document, http://www.salon.com/2017/02/11/noam-chomskys-responsibility-ofintellectuals-after-50-years-its-an-even-heavier-responsibility-now/. Accessed 11 February 2017.

Patterson, T.C.

1999. The Political Economy of Archaeology in the United States. Annual Review of Anthropology 28:155-174.

Plets, G.

2016a. Heritage Bureaucracies and the Modern Nation State. Towards an Ethnography of Archaeological Systems of Government. Archaeological Dialogues 23(2):193-213.

2016b. Heritage Statecraft: When Archaeological Heritage meets Neoliberalism in Gazprom's Resource Colonies, Russia. Journal of Field Archaeology 41(3):368-383.

Poulantzas, N.

1968. Political Power and Social Classes. New Left Books, London.

Poulantzas, N., and R. Miliband

1972. The Problem of the Capitalist State. In Ideology in Social Science: Readings 
in Critical Social Theory, edited by R. Blackburn, pp. 238-262. Pantheon Books, New York, NY.

Radcliffe-Brown, A.R.

1940. Preface. In African Political Systems, edited by M. Fortes and E. E. EvansPritchard, pp. xi-xxiii. Oxford University Press, London.

Rose, N., and P. Miller

2010. Political Power Beyond the State: Problematics of Government. The British Journal of Sociology 61(1):271-303.

Scott, J.C.

1998. Seeing Like a State: How Certain Schemes to Improve the Human Condition Have Failed. Yale University Press, New Haven.

2010. The Trouble with the View from Above. CATO Institute September 8 . Electronic document, http://www.cato-unbound.org/2010/09/08/james-cscott/trouble-view-above. Accessed 17 May 2016.

Shnirelman, V.

2014. Nationalism and Archaeology: Overview. In Encyclopedia of Global Archaeology, edited by C. Smith, pp. 5149-5161. Springer, New York, NY.

Simpson, A.

2016. The State is a Man: Theresa Spence, Loretta Saunders and the Gender of Settler Sovereignty. Theory \& Event 19(4). Project MUSE, muse.jhu.edu/ article/633280.

Skocpol, T.

1985. Bringing the State Back. In Strategies for Analysis in Current Research, edited by P. Evans, D. Rueschemeyer, and T. Skocpol, pp. 3-43. Cambridge University Press, Cambridge.

Smith, L.

2004. Archaeological Theory and the Politics of Cultural Heritage. Routledge, London.

Thomas, J.

2004. Archaeology and Modernity. Routledge, London.

Trigger, B.G.

1984. Alternative Archaeologies: Nationalist, Colonialist. Imperialist. Man 19(3):355-370.

2006. A History of Archaeological Thought (2nd ed.). Cambridge University Press, Cambridge.

Weber, M.

1987. Economy and Society: An Outline of Interpretive Sociology. University of California Press, Berkeley, CA.

Zetterstrom-Sharp, J.

2015. Heritage as Future-Making: Aspiration and Common Destiny in Sierra Leone. International Journal of Heritage Studies 21(6):609-627. 